\title{
ANALISIS FAKTOR-FAKTOR PENYEBAB KEKUMUHAN DI PERMUKIMAN PESISIR KAMPUNG TUA TANJUNG RIAU
}

\author{
${ }^{1}$ Carissa Dinar Aguspriyanti, ${ }^{2}$ Fanny Nimita, ${ }^{3}$ Deviana \\ 1-3Universitas Internasional Batam, Batam, Indonesia \\ carissa@uib.ac.id ${ }^{1}$
}

\author{
Informasi Naskah \\ Diterima: 14/12/2020; Disetujui terbit: 29/12/2020; Diterbitkan: 29/12/2020; \\ http://journal.uib.ac.id/index.php/jad
}

\begin{abstract}
ABSTRAK
Keberadaan permukiman sebagai tempat penduduk beraktivitas dan juga tinggal sering kali menemui berbagai permasalahan yang dapat mengganggu aktivitas permukiman penduduk setempat. Salah satu isu yang masih sulit untuk dihindari dalam perkembangan wilayah kotakota di Indonesia adalah pertumbuhan permukiman kumuh. Fenomena tersebut dapat dijumpai pada permukiman pesisir Kampung Tua Tanjung Riau. Kampung Tua Tanjung Riau sendiri merupakan salah satu Kampung Tua bersejarah di Kota Batam yang berada di kecamatan Sekupang. Dengan melihat lokasi dan sejarahnya, permukiman pesisir tersebut memiliki potensi sebagai salah satu tempat wisata Kampung Tua di kota Batam. Oleh karena itu, diperlukan identifikasi faktor-faktor penyebab kekumuhan di permukiman tersebut, sehingga tingkat kekumuhan yang mempengaruhi kelayakan huni permukiman tersebut dapat diminimalisir, serta potensinya sebagai tempat wisata nantinya dapat dikembangkan secara optimal. Penelitian ini berfokus pada indikator-indikator fisik kawasan yang beresiko menyebabkan kekumuhan. Hasil penelitian menunjukkan bahwa faktor-faktor penyebab kekumuhan di permukiman pesisir Kampung Tua Tanjung Riau adalah aksesibilitas yang terbatas, sebagian jalan permukiman memiliki kondisi yang buruk, tingkat kepadatan bangunan cukup tinggi, tidak terdapat keteraturan pola penataan rumah-rumah, kualitas mayoritas bangunan yang rendah, minimnya ketersediaan jaringan drainase dan sanitasi yang baik, serta nihilnya sistem pengelolaan sampah yang terintegrasi. Selanjutnya, peneliti memberikan rekomendasi solusi mengatasi permasalahan berdasarkan faktor-faktor tersebut.
\end{abstract}

Kata Kunci: permukiman kumuh, permukiman pesisir, Kampung Tua Tanjung Riau

\begin{abstract}
The existence of settlements as a place for people to do activities and also live often encounter various problems that can disrupt the local residents' activities. One of the issues, which is still difficult to avoid in the development of urban areas in Indonesia, is the emergence of urban slums. This phenomenon can be found in the coastal settlements of Kampung Tua Tanjung Riau. It is one of the historic old villages in Batam City, which is located in the Sekupang subdistrict. By looking at its location and history, this coastal settlement has the potential as one of the tourist attractions for Kampung Tua in Batam city. Therefore, it is necessary to identify the factors that cause slums in this settlement so that the level of slum which affects the habitability of this settlement can be minimized, and its potential as a tourist spot can subsequently be developed optimally. This research focuses on physical indicators of areas that are at risk of causing slums. The results of this research show that the factors causing slum in the coastal settlement of Kampung Tua Tanjung Riau are limited accessibility, the poor quality of some settlements roads, the high level of building density, the irregularity of the arrangement of houses, the low quality of the majority of buildings, the poor quality of drainage and sanitation networks as well as the unavailability of an integrated waste management system. Furthermore, recommendations to overcome the problems based on these factors are provided.
\end{abstract}

Keywords: slum, coastal settlement, Kampung Tua Tanjung Riau 


\section{PENDAHULUAN}

Permukiman adalah suatu kawasan yang dihuni oleh sekelompok masyarakat yang membangun rumah pada lahan kosong sehingga menyebabkan pola penataan pada kawasan tersebut cenderung menjadi tidak beraturan. Permukiman memiliki tingkat kepadatan penduduk yang cukup tinggi.

Sama halnya dengan permukiman pada umumnya, permukiman pesisir yang merupakan kawasan permukiman di daerah pesisir juga tidak jarang menemui permasalahan. Permasalahan yang sering kali muncul pada permukiman pesisir adalah adanya kasus yang berkaitan dengan bencana alam. Akan tetapi, ada juga faktor lain yang menimbulkan permasalahan bagi masyarakat setempat, seperti rendahnya kualitas lingkungan sekitar dan kondisi sarana dan prasarana yang tersedia kurang dapat menunjang kehidupan masyarakat sehingga mereka menjadi tidak nyaman dalam menjalani kehidupan sehari-hari.

Tingkat kualitas suatu lingkungan dapat dilihat dari kebersihan lingkungan tersebut. Rendahnya kebersihan lingkungan dapat mengakibatkan penurunan kualitas tempat tersebut untuk dihuni oleh masyarakat karena akan membahayakan kesehatan. Kondisi lingkungan permukiman yang tidak memiliki kualitas baik untuk ditinggali atau memiliki lingkungan yang kotor cenderung menyebabkan terbentuknya permukiman kumuh.

Walaupun tidak diharapkan, keberadaan permukiman kumuh menjadi hal yang biasa terlihat dalam perkembangan sebuah kota, tidak terkecuali di Kota Batam. Tanjung Riau yang memiliki memiliki luas wilayah sebesar 43,67 hektar (Humas Batam, 2013) merupakan salah satu kampung tua yang terletak di kecamatan Sekupang, Kota Batam, Kepulauan Riau.

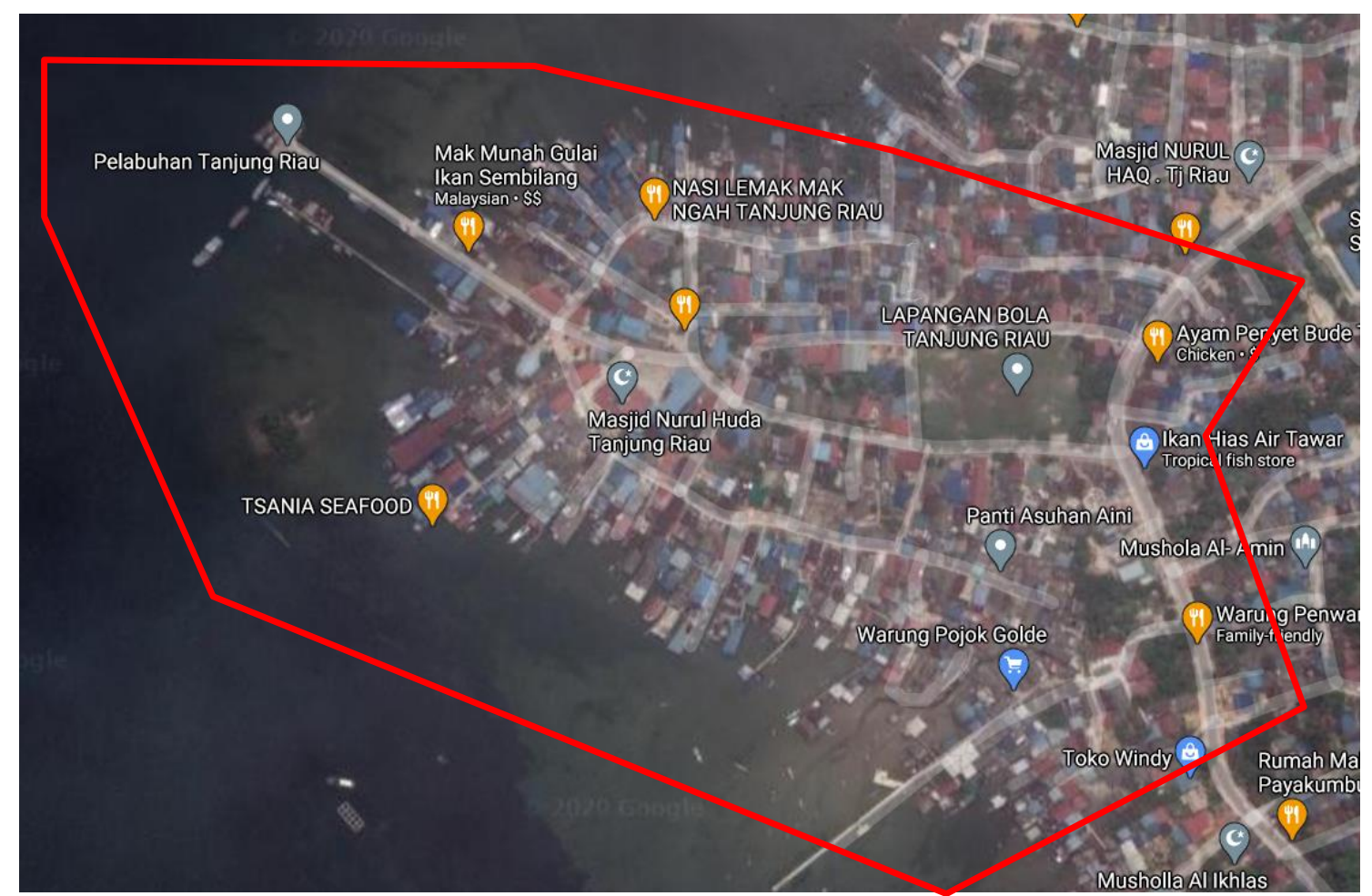

Gambar 1. Lokasi Permukiman Pesisir Kampung Tua Tanjung Riau Sumber: Google Map, 2020

Kampung Tua Tanjung Riau merupakan permukiman pesisir yang dapat tergolong sebagai permukiman kumuh karena berdasarkan pengamatan awal terdapat sampah-

177 I JAD - Vol.01/No.02, Desember 2020 
sampah yang berserakan di permukiman tersebut, baik di area perairan maupun daratan. Selain itu, kondisi jalan dan rumah tinggal masyarakat setempat juga terlihat minim penataan. Padahal Kampung Tua Tanjung Riau merupakan salah satu permukiman pesisir di Kota Batam yang berpotensi menjadi kawasan wisata.

Berdasarkan permasalahan yang telah diuraikan diatas, maka dilakukan penelitian terhadap faktor-faktor penyebab kekumuhan di permukiman pesisir Kampung Tua Tanjung Riau, guna meningkatkan kesadaran masyarakat untuk menjaga kebersihan pada lingkungan sekitar dan memberikan alternatif solusi untuk menjadikan permukiman kumuh tersebut menjadi permukiman yang lebih layak huni.

\section{KAJIAN PUSTAKA}

\subsection{Definisi Permukiman Pesisir}

Permukiman merupakan bagian dari lingkungan hunian yang terdiri atas lebih dari satu satuan perumahan yang mempunyai prasarana, sarana, utilitas umum, serta mempunyai penunjang kegiatan fungsi lain di kawasan (Undang-Undang Nomor 4 Tahun 1992). Menurut Hadi Sabari Yunus (1987) dalam Wesnawa (2015) permukiman dapat diartikan sebagai bentukan yang dibuat manusia maupun bentukan yang alami dengan segala fasilitas penunjang yang dapat digunakan manusia sebagai individu maupun kelompok dalam kehidupan untuk mendapatkan tempat tinggal dalam waktu sementara maupun selamanya. Budihardjo (1997) menambahkan bahwa permukiman manusia merupakan masalah yang sangat rumit, yang saling berkaitan satu sama lain karena menyangkut wadah dan isi. Bagian permukiman yang disebut wadah tersebut dapat dikatakan merupakan paduan tiga unsur dari kelima unsur pembentuk sistem permukiman yang dikemukakan oleh Doxiadis (Kuswartojo \& Salim, 1997) yakni alam yang terdiri dari tanah, air dan udara; lindungan, seperti rumah, gedung, dan lainnya; jaringan, seperti jalan, jaringan utilitas, dan sebagainya. Sedangkan, unsur keempat dan kelima yang mengisi sistem permukiman adalah manusia (penghuni) dan masyarakat.

Dengan demikian, permukiman pesisir merupakan lingkungan hunian yang dilengkapi dengan fasilitas penunjang kehidupan di kawasan pesisir yang notabene merupakan perbatasan antara wilayah perairan dan daratan. Segala aktivitas penggunaan lahan di wilayah tersebut mempengaruhi fungsi kelautan setempat (Kay \& Alder, 1999).

\subsection{Definisi Permukiman Kumuh}

Dalam Undang-Undang Nomor 1 Tahun 2011 tentang Perumahan dan Kawasan Permukiman (2011), permukiman kumuh adalah permukiman yang tidak layak huni karena ketidakteraturan bangunan, tingkat kepadatan bangunan yang tinggi, dan kualitas bangunan serta sarana dan prasarana yang tidak memenuhi syarat.

Menurut Komarudin (1997) dan Yudohusodo dalam Ridlo (2001), lingkungan permukiman kumuh dapat didefinisikan sebagai lingkungan permukiman yang memiliki kondisi fisik buruk - jumlah dan pola penataan rumah-rumah cenderung padat melebihi 500 orang per Ha dengan bentuk yang tidak berstruktur, umumnya dengan ukuran di bawah standar, dan pola jalan tidak beraturan, serta minimnya ketersediaan sarana dan prasarana yang memenuhi syarat teknis dan kesehatan - dan kondisi sosial serta ekonomi masyarakatnya tergolong rendah. Dari segi legalitas, umumnya hunian-hunian di permukiman kumuh dibangun di atas tanah milik negara atau orang lain.

Dengan kata lain, permukiman kumuh dapat didefinisikan sebagai kawasan permukiman yang terbentuk tanpa legalitas yang jelas, dan sebagai dampak status illegal 
atau semi-ilegal tersebut, kondisi infrastruktur dan prasarana pendukungnya cenderung tidak memenuhi standar (Srinivas, 2015).

\subsection{Indikator Permukiman Kumuh}

Dari definisinya, kriteria untuk menentukan kekumuhan suatu lokasi permukiman dapat dilihat dari aspek fisik dan non-fisik. Faktor-faktor yang menyebabkan kekumuhan di kawasan permukiman menurut Nawagumura dan Viking (2003), Damisi (2014), dan Sekatia (2015) dapat dirangkum menjadi Tabel 1.

Tabel 1. Indikator Permukiman Kumuh

\begin{tabular}{|c|c|c|}
\hline \multicolumn{2}{|c|}{ Aspek } & Kriteria \\
\hline \multirow[t]{8}{*}{ Fisik } & \multirow{2}{*}{$\begin{array}{l}\text { Kondisi aksesibilitas } \\
\text { (jalan lingkungan) }\end{array}$} & $\begin{array}{l}\text { (1) Keterjangkauan } \\
\text { jaringan jalan }\end{array}$ \\
\hline & & (2) Kualitas jalan \\
\hline & \multirow{3}{*}{ Kondisi bangunan } & $\begin{array}{c}\text { (1) Kepadatan } \\
\text { bangunan }\end{array}$ \\
\hline & & \begin{tabular}{|c|}
$\begin{array}{c}\text { (2) Keteraturan } \\
\text { bangunan }\end{array}$ \\
\end{tabular} \\
\hline & & (3) Kualitas bangunan \\
\hline & \multirow{3}{*}{$\begin{array}{l}\text { Kondisi sarana dan } \\
\text { prasarana dasar }\end{array}$} & $\begin{array}{l}\text { (1) Kualitas drainase } \\
\text { dan sanitasi } \\
\text { lingkungan }\end{array}$ \\
\hline & & $\begin{array}{l}\text { (2) Ketersediaan air } \\
\text { bersih }\end{array}$ \\
\hline & & \begin{tabular}{|l|} 
(3) Ketersediaan \\
sistem pengelolaan \\
sampah
\end{tabular} \\
\hline \multirow[t]{5}{*}{$\begin{array}{l}\text { Non } \\
\text { Fisik }\end{array}$} & Kependudukan & $\begin{array}{l}\text { Tingkat pertumbuhan } \\
\text { penduduk }\end{array}$ \\
\hline & \multirow[t]{3}{*}{ Kondisi Sosial Ekonomi } & (1) Tingkat pendidikan \\
\hline & & (2) Tingkat pendapatan \\
\hline & & (3) Jenis Pekerjaan \\
\hline & Legalitas & $\begin{array}{l}\text { Kepemilikan } \\
\text { hunian/lahan }\end{array}$ \\
\hline
\end{tabular}

Sumber: Pribadi, 2020

Pada dasarnya, permukiman kumuh dapat secara langsung diidentifikasi dari karakteristik fisiknya, walaupun aspek fisik dan non-fisik tersebut saling mempengaruhi. Sarana dan prasarana yang tidak memenuhi syarat disebabkan oleh kemampuan pemerintah yang terbatas dalam pengelolaan serta pengadaan sarana dan prasarana lingkungan permukiman yang tidak memiliki legalitas yang jelas. Selain dari kemampuan pemerintah yang terbatas, kemampuan, kapasitas serta kesadaran masyarakat juga terbatas dalam peningkatan permasalahan sarana dan prasarana. Hal ini dapat dipengaruhi oleh tingkat pendidikan dan pendapat masyarakat tersebut.

\section{METODE PENELITIAN}

Penelitian yang menggunakan metode kualitatif deskriptif ini berfokus pada aspek fisik 
penyebab kekumuhan di kawasan permukiman pesisir, yang tertuang pada Tabel 1. Oleh karena itu, data primer diperoleh dari hasil survei atau observasi permukiman pesisir Kampung Tua Tanjung Riau. Observasi dilakukan melalui teknik pengamatan langsung dan dilengkapi dengan dokumentasi. Sedangkan data sekunder diperoleh melalui literatur yang berkaitan dengan tema penelitian yang dilakukan, baik melalui jurnal, buku maupun artikel yang berkaitan dengan teori-teori pendapat oleh para ahli tentang pembahasan studi yang diangkat. Data-data tersebut kemudian dianalisis untuk mendapatkan faktor-faktor penyebab kekumuhan di lokasi penelitian. Kemudian peneliti memberikan rekomendasi solusi sebagai tanggapan terhadap faktor-faktor tersebut.

\section{HASIL DAN PEMBAHASAN}

\subsection{Kondisi Aksesibilitas (Jalan Lingkungan)}

\section{Keterjangkauan jaringan jalan}

Jaringan jalan yang lebar dan beraspal masih belum melayani seluruh lingkungan permukiman. Jalan utama sebagai akses masuk kawasan permukiman memiliki lebar kurang lebih lima meter. Selain jalan utama tersebut, permukiman pesisir Kampung Tua Tanjung Riau memiliki jalan yang lebarnya sekitar 1-1,5 meter sehingga sebagian besar jalan pada permukiman ini hanya dapat dilalui oleh sepeda motor dan pejalan kaki saja.

\section{Kualitas jalan}

Kualitas permukaan jalan di beberapa titik masih dalam kondisi bagus, namun tidak semua jalan bermaterialkan aspal. Hal ini dikarenakan posisi sebagian rumah di permukiman ini berlokasi di perairan, sehingga masih menggunakan kayu. Selain itu, luasan jalan yang sempit di sebagian besar area permukiman juga mengurangi kenyamanan dan aksesibilitas permukiman tersebut. Apalagi ketidaktersediaan pagar pengaman di sepanjang jalan tersebut beresiko membahayakan keselamatan pengguna jalan, apalagi ketika harus berpapasan dengan pengendara motor.

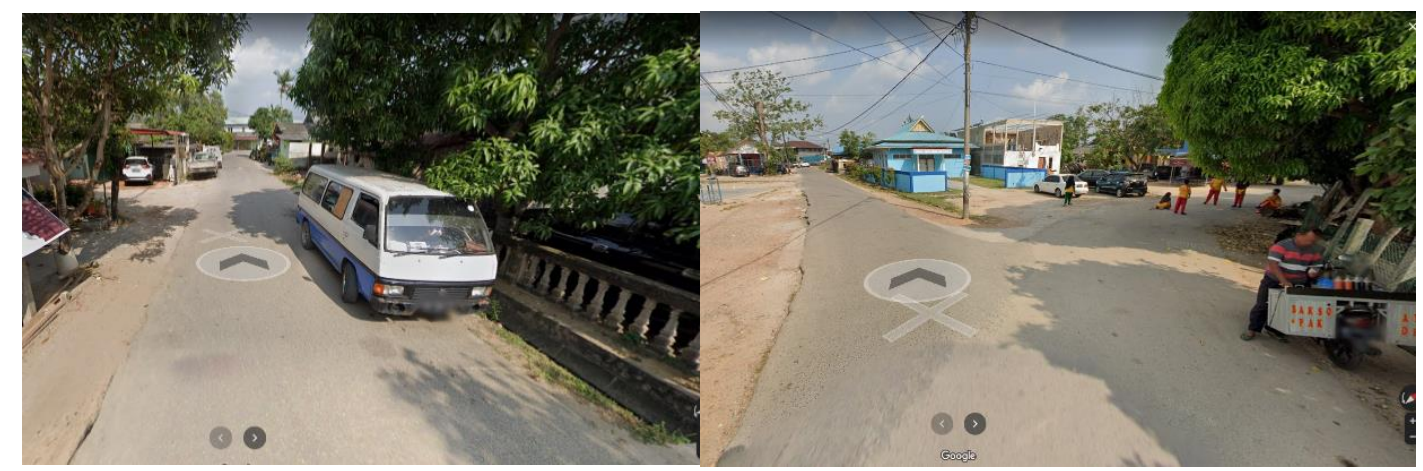

Gambar 2. Jalan Utama Menuju Permukiman Pesisir Kampung Tua Tanjung Riau Sumber: Google Maps, 2020 


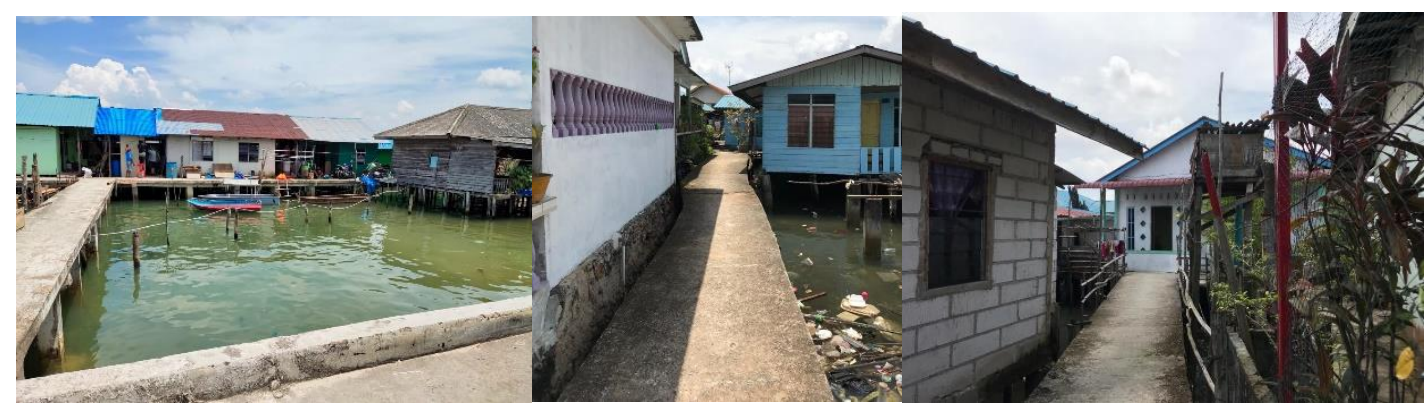

Gambar 3. Jalan pada Permukiman Pesisir Kampung Tua Tanjung Riau

Sumber: Pribadi, 2020

\subsection{Kondisi Bangunan}

\section{Kepadatan bangunan}

Seiring dengan meningkatnya perkembangan wilayah di Kampung Tua Tanjung Riau, kondisi bangunan permukiman pun semakin padat. Tingginya kepadatan bangunan di kawasan ini mempengaruhi ketersediaan ruang terbuka khususnya ruang terbuka hijau $(\mathrm{RTH})$. Hal ini dapat berdampak pada tingkat suhu udara kawasan. Jika di suatu lokasi tingkat kepadatan bangunannya semakin tinggi maka potensi kenaikan suhu di lokasi tersebut juga meningkat.

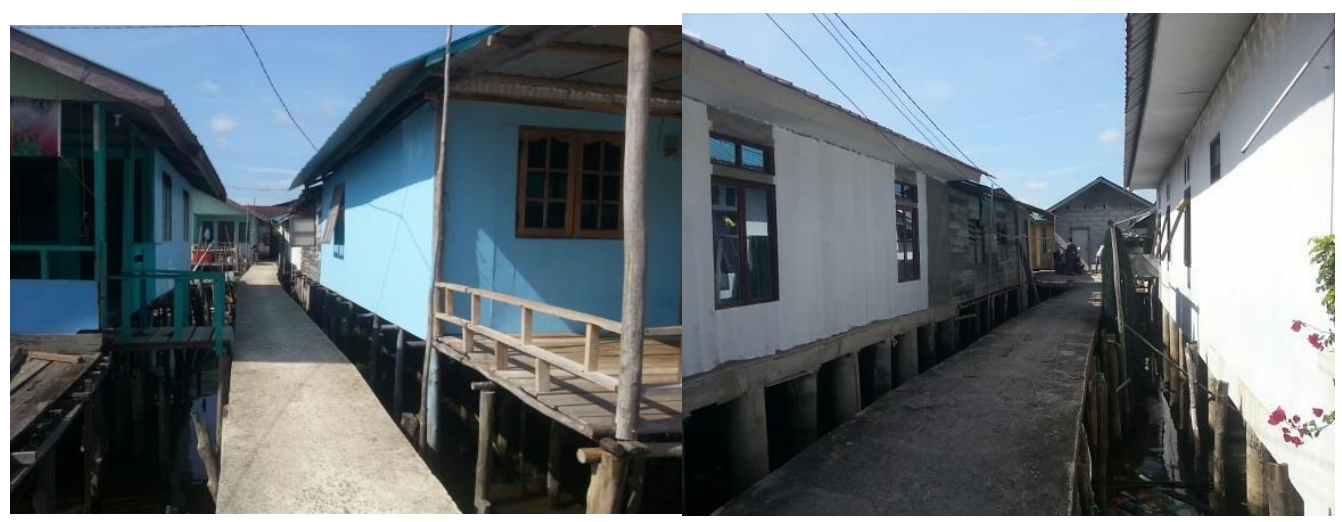

Gambar 4. Kepadatan Bangunan di Kampung Tua Tanjung Riau Sumber: Pribadi, 2020

\section{Keteraturan bangunan}

Penyusunan bangunan-bangunan pada Kampung Tua Tanjung Riau masih bisa terbilang belum cukup tertata. Masih terlihat adanya bangunan yang tidak bersusun rapi antar bangunan yang membuat kondisi wilayah pada permukiman Kampung Tua Tanjung Riau secara keseluruhan menjadi kurang tersusun. 


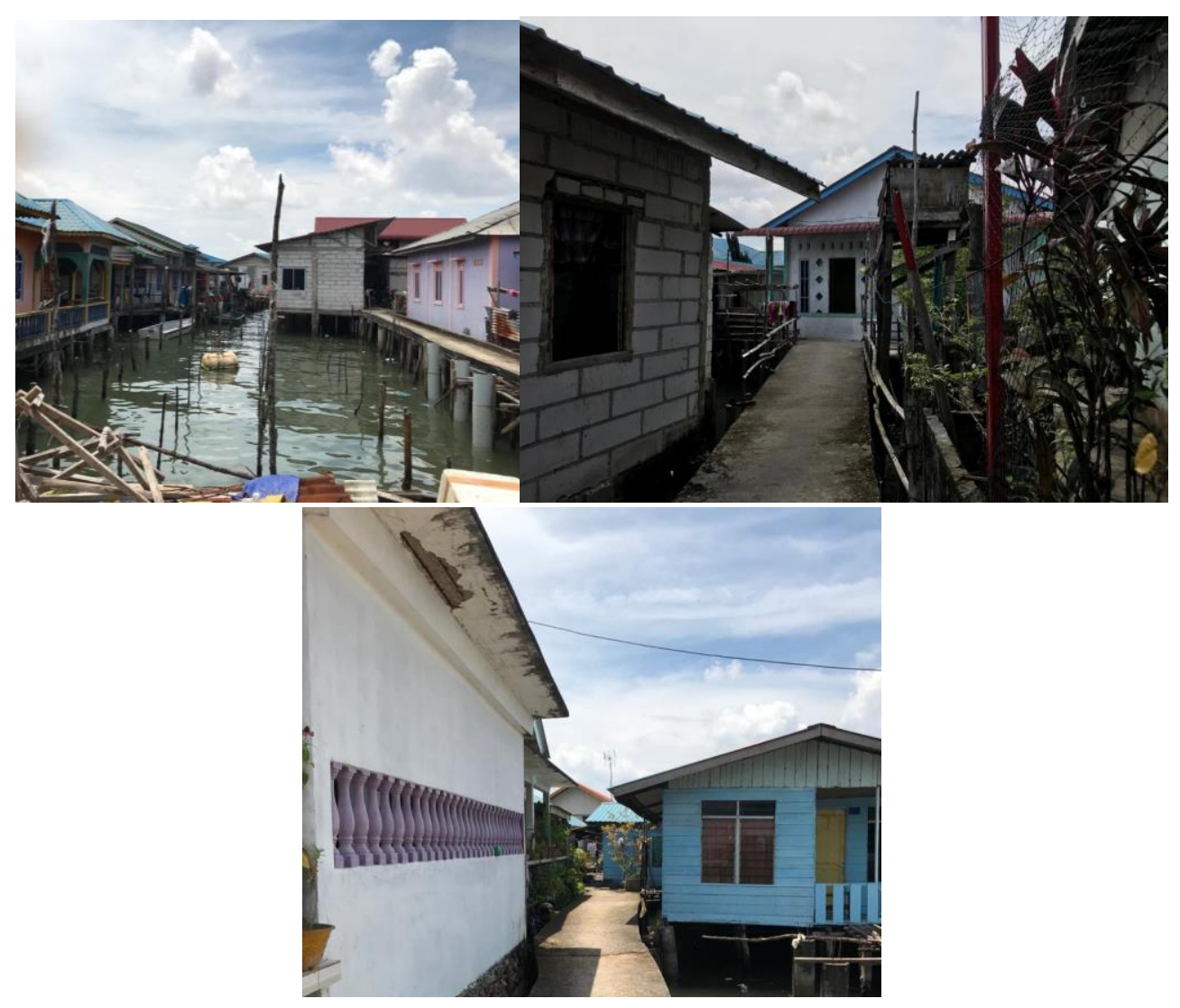

Gambar 5. Tempat Tinggal Penduduk yang Tidak Beraturan Sumber: Pribadi, 2020

\section{Kualitas bangunan}

Kualitas bangunan Kampung Tua Tanjung Riau bisa dibilang cukup bagus, karena sebagian sudah menggunakan material modern seperti bata, semen dan besi. Meskipun demikian, ada juga ditemukan di beberapa tempat yang masih menggunakan material lama seperti kayu yang sudah tidak kuat dan kokoh pada rumah panggung Kampung Tua Tanjung Riau.

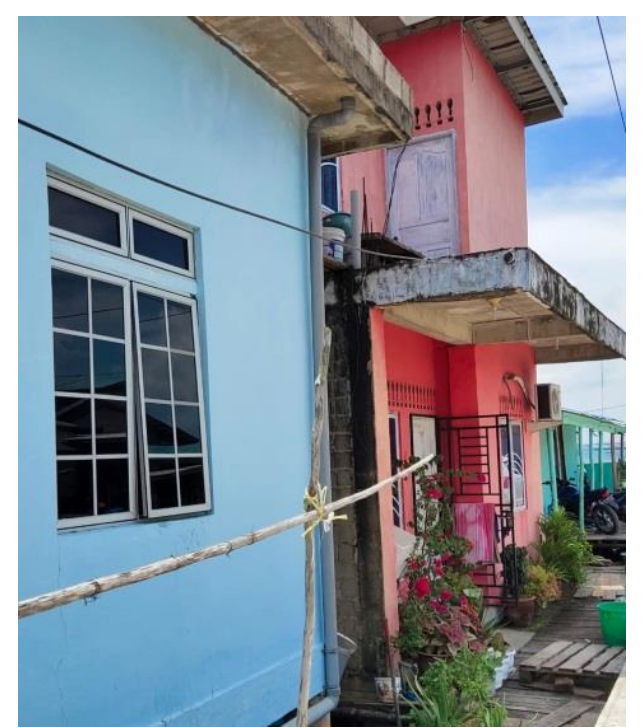

Gambar 6. Tempat Tinggal Penduduk dengan Material Modern Sumber: Pribadi, 2020 


\subsection{Kondisi Sarana dan Prasarana Dasar}

\section{Kualitas drainase dan sanitasi lingkungan}

Ketersediaan jaringan drainase dan sanitasi di permukiman pesisir Kampung Tua Tanjung Riau masih sangat minim. Rumah-rumah yang berada diatas laut masih banyak yang tidak memiliki jaringan sanitasi seperti bak kontrol dan septic tank sehingga pembuangan air kotor seperti air cucian, air bekas hingga air mandi masih dibuang secara langsung ke air laut. Oleh karena itu, air laut yang berada di daerah permukiman penduduk tersebut sangatlah kumuh dan tercemar.

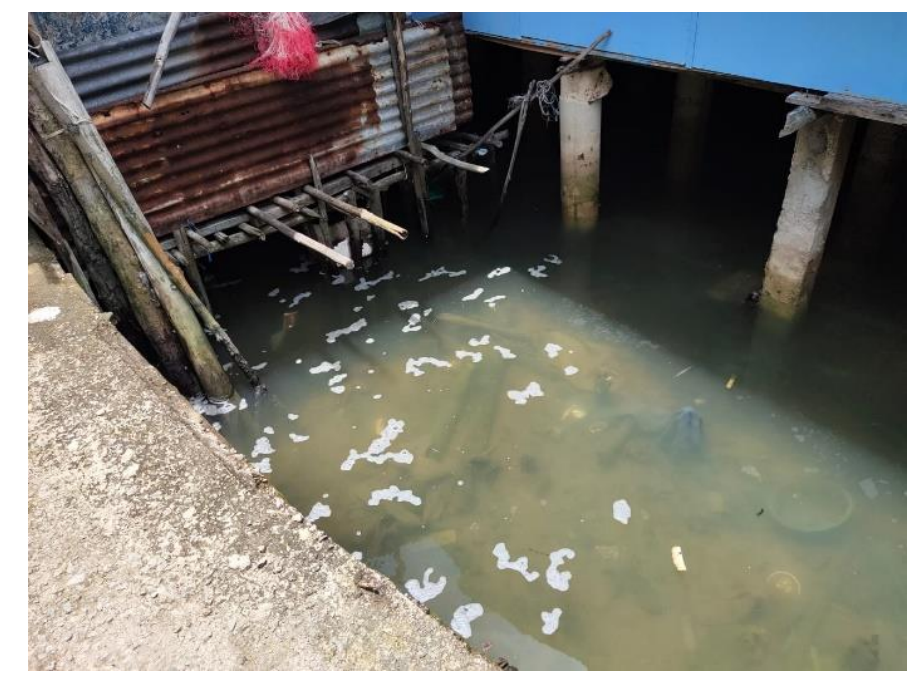

Gambar 4. Pembuangan Air Kotor Secara Langsung ke Laut Sumber: Pribadi, 2020

Pada tahun 2020, pembuatan jaringan sanitasi secara komunal pada permukiman Kampung Tua Tanjung Riau telah selesai. Namun, jaringan sanitasi tersebut belum merata di seluruh kawasan permukiman, hanya dibeberapa titik saja. Jaringan sanitasi tersebut adalah bak kontrol dan septic tank. Jaringan sanitasi tersebut masih dalam kondisi baik dikarena baru dibuat pada tahun 2020.

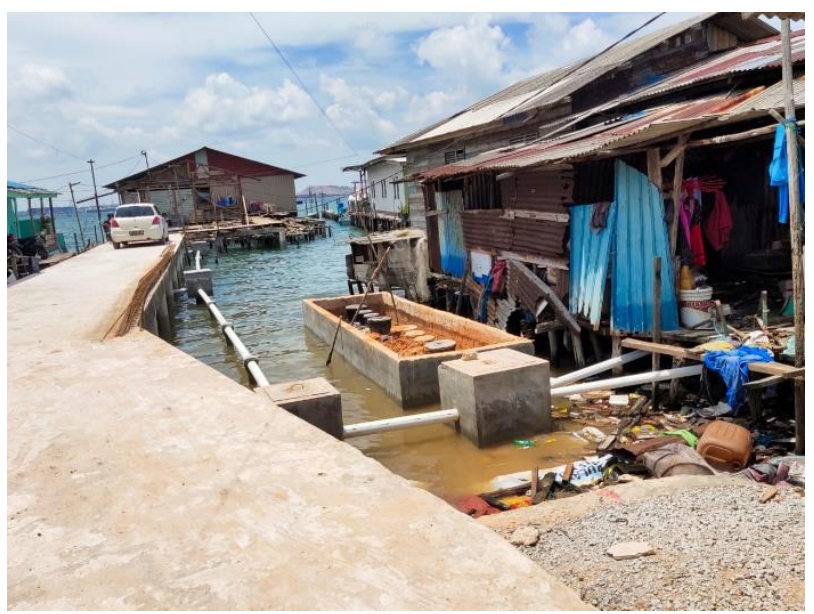

Gambar 5. Jaringan Sanitasi Komunal Permukiman Pesisir Kampung Tua Tanjung Riau Sumber: Pribadi, 2020 


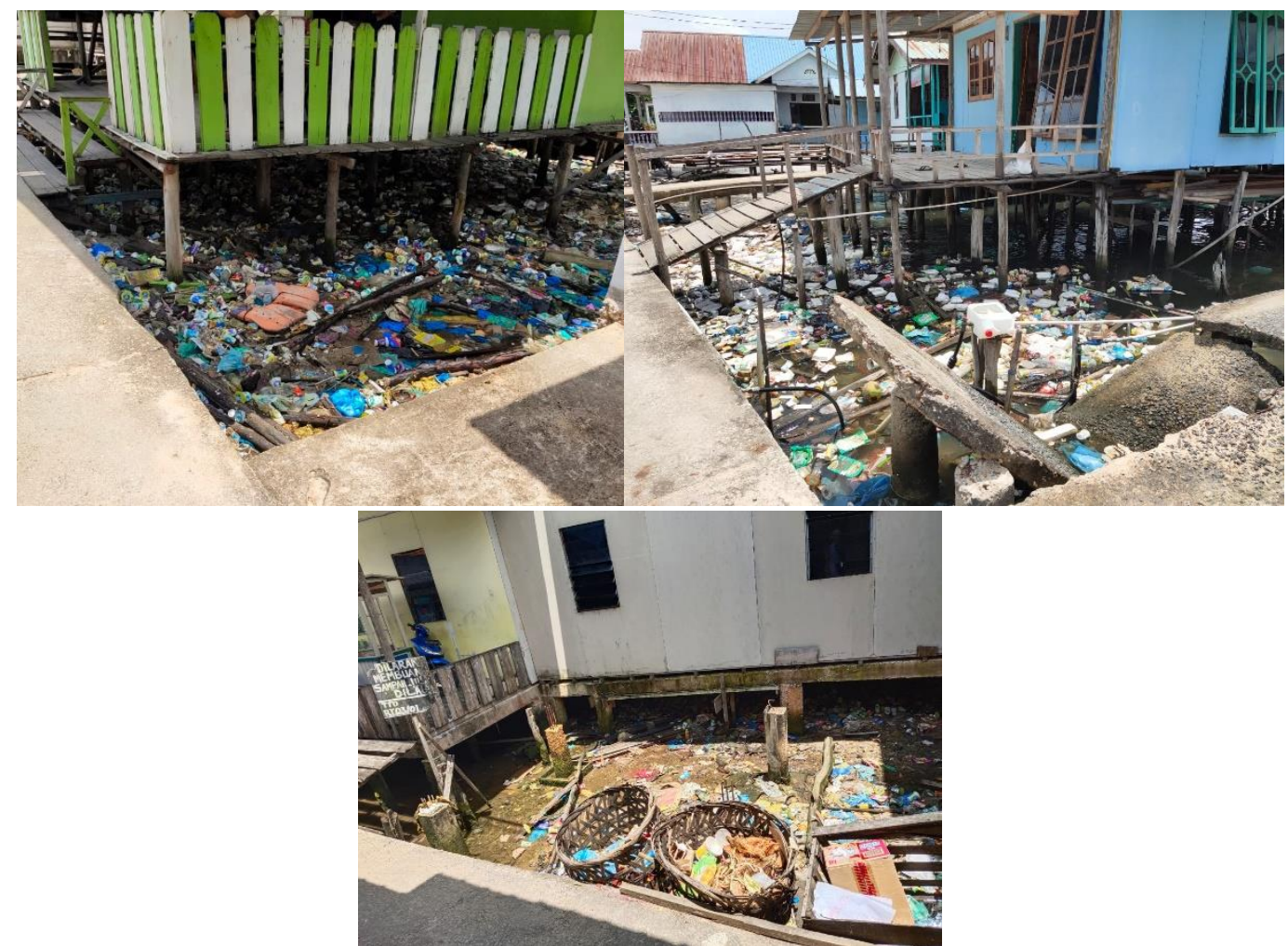

Gambar 6. Kondisi Lingkungan yang dipenuhi oleh Sampah

Sumber: Pribadi, 2020

\section{Ketersediaan air bersih}

Ketersediaan saluran air bersih pada kawasan permukiman pesisir Kampung Tua Tanjung Riau bisa dikatakan dapat menunjang kebutuhan masyarakat dengan baik. Pada daerah daratan di permukiman Kampung Tua Tanjung Riau sudah memakai meteran untuk mendapatkan air bersih. Namun, pada daerah laut masih terdapat penduduk yang memanfaatkan air laut dalam memenuhi kebutuhan air bersih. Sebenarnya, penggunaan air laut sebagai air bersih ini dinilai kurang baik, dikarenakan adanya sampah-sampah serta air kotor yang di buang ke dalam air laut sehingga dapat menimbulkan wabah penyakit.

\section{Ketersediaan sistem pengelolaan sampah}

Di kawasan permukiman pesisir Kampung Tua Tanjung Riau belum terdapat sistem pengelolaan sampah yang baik. Hal ini tercermin dari banyaknya sampah-sampah yang tergenang di laut, di depan rumah, di tepi jalan, di bawah rumah panggung hingga di lahan kosong yang telah memiliki peringatan untuk tidak membuang sampah di lahan tersebut (lihat Gambar 6). Akan tetapi, tingkat kesadaran masyarakat sekitar masih sangat rendah. Tidak ada aksi dari masyarakat untuk membersihkan atau mengelola sampah-sampah tersebut sehingga tingkat kekumuhan terus meningkat. Lingkungan pada permukiman juga semakin tercemar dan tidak sehat. Lingkungan tersebut akan membahayakan masyarakat sekitar karena akan lebih mudah membawa wabah penyakit.

\section{Kesimpulan}

Dari hasil penelitian yang dilakukan dapat disimpulkan bahwa di kawasan permukiman pesisir Kampung Tua Tanjung Riau:

1. Belum semua area dapat diakses dengan mudah. 
2. Belum semua jalan memiliki kondisi yang baik.

3. Tingkat kepadatan bangunan cukup tinggi.

4. Tidak terdapat keteraturan pola penataan rumah-rumah.

5. Mayoritas rumahnya memiliki kualitas bangunan yang rendah.

6. Ketersediaan jaringan drainase dan sanitasi lingkungan yang baik masih minim.

7. Ketersediaan air bersih masih belum tersedia dengan merata.

8. Belum memiliki sistem pengelolaan sampah yang baik dan terintegrasi.

Hal-hal tersebut menjadi faktor-faktor utama penyebab kekumuhan di permukiman pesisir Kampung Tua Tanjung Riau.

\section{Rekomendasi}

1. Kawasan permukiman pesisir kampung Tua Tanjung Riau merupakan salah satu kawasan yang berpotensi menjadi area wisata di Kota Batam, sehingga diperlukan upaya perbaikan dari pemerintah dan masyarakat guna meminimalisir tingkat kekumuhan di kawasan tersebut.

2. Solusi untuk mengatasi sistem pengelolaan sampah yang kurang baik adalah dengan meningkatkan kesadaran penduduk melalui pembentukan komite kebersihan yang beranggotakan warga setempat, memperbanyak tempat sampah dengan sistem pemilahan sampah pada skala dosmetik atau rumah tangga dan membuat tempat pengumpulan sampah dengan sistem 3R (Reduce, Reuse, Recycle).

3. Solusi untuk mengatasi sarana dan prasarana dasar yang kurang memadai adalah menerapkan serta menambahkan jaringan sanitasi dengan sistem terpusat secara merata. Jaringan sanitasi dengan sistem terpusat ini adalah sistem septic tank komunal. Sistem ini terdiri dari unit pengolah limbah, jaringan perpipaan yaitu bak kontrol dan lubang perawatan, dan sambungan pada rumah tangga.

4. Untuk rekomendasi penelitian lanjutan, dapat dilakukan penelitian bertemakan sejenis dengan turut meninjau aspek non-fisik dan perencanaan penataan ulang kawasan permukiman pesisir Kampung Tua Tanjung Riau.

\section{DAFTAR PUSTAKA}

Budihardjo, e. (1997). Lingkungan binaan dan tata ruang kota. Andi.

Damisi, d. M., kumurur, v. A., \& sela, r. L. E. (2014). Analisis faktor-faktor kekumuhan kawasan permukiman pesisir tradisional (studi kasus: desa bajo kecamatan tilamuta, kabupaten boalemo provinsi gorontalo). Sabua, 6(1), 163-172.

Humas batam. (2013). Masyarakat tanjung riau gelar syukuran dan launching kampung tua. Https://mediacenter.batam.go.id/arsip/humas/index.html\%3fp=22507.html

Kay, r., \& alder, j. (1999). Coastal planning and management. E\&fn spon.

Komarudin. (1997). Menelusuri pembangunan perumahan dan pemukiman. Yayasan real estate indonesia.

Kuswartojo, t., \& salim, s. A. (1997). Perumahan dan permukiman yang berwawasan lingkungan. Direktorat jenderal pendidikan tinggi departemen dan kebudayaan. 
Nawagamuwa, a., \& viking, n. (2003). Slums, squatter areas and informal settlementsdo they block or help urban sustainability in developing contexts? Proceedings of the 9th international conference on sri lanka studies, 1-12.

Ridlo, m. A. (2001). Kemiskinan di perkotaan. Penerbit uninssula.

Sekatia, a. (2015). Kajian permukiman kumuh dan nelayan tambak lorok semarang studi kasus partisipasi masyarakat. Modul, 15(1), 57-66. Https://doi.org/10.14710/mdl.15.1.2015.57-66

Srinivas, h. (2015). Defining squatter settlements. Urban squatters and slums, concept note series e-036.

Undang-undang nomor 1 tahun 2011. (2011). Perumahan dan kawasan permukiman. Lembaran negara republik indonesia tahun 2011 nomor 7.

Undang-undang nomor 4 tahun 1992. (1992). Perumahan dan permukiman. Lembaran negara republik indonesia tahun 1992 nomor 23.

Wesnawa, i. G. A. (2015). Geografi permukiman. Graha ilmu yogyakarta. 